821.163.41.08-32 Андрић И.

811.163.41'367.62

https://doi.org/10.18485/kij.2020.67.1.8

МИРЈАНА М. СТАКИЪ ${ }^{*}$

Оригинални научни рад

Универзитет у Крагујевцу

Примљен: 08.05.2020.

Педагошки факултет у Ужицу

Прихваћен: 04.06.2020.

\title{
ЕКСПРЕСИВНОСТ АНДРИЋЕВЕ ПРИПОВЕТКЕ У ЗАВАДИ СА СВЕТОМ**
}

\begin{abstract}
У раду испитујемо експресивност Андрићеве приповетке $У$ завади са светом са нагласком на емоционалну компоненту испољене експресије. Истражујемо експресивност насловне синтагме и понављања у тексту приповетке значењски маркиране лексеме сумњив. Испитиване експресивне елементе посматрамо као саодносне елементе слојевите и значењски богате структуре текста. Њиховом анализом сагледавамо кодни шум и позитивну редунданцу, тумачимо рефлексивне слојеве приповетке, маркирана психолошка значења и деловање на личност главног јунака трауматичног доживљаја.
\end{abstract}

Кључне речи: српски језик, експресивност, емоционалност, лексема сумњив, Иво Андрић, приповетка У завади са светот.

\section{Уводно разматрање}

Експресивност се јавља на свим језичким нивоима (Симић/Јовановић 2002: 356-358) и дефинише као висока изражајност која се постиже употребом адекватних језичких јединица (према: Бјелаковић 2016: 161). По Штрасни, феномен експресивности се уочава у „дихотомним парадигмама у којима се супротстављају маркираност и немаркираност језичког израза" (Штрасни 2016: 349). Тошовић суочава појам експресивности са појмовима емоционалности, стилистичке обојености, конотативности, изражајности, сликовитости и естетичности и закључује да „ниједна од наведених категорија не чини са експресивношћу однос потпуне идентичности, јер им се обими разликују” (Тошовић 2004: 37). И

*mirjanastakic073@gmail.com

** Рад је настао у оквиру пројекта Настава и учење: проблеми, циљеви и перспективе, бр. 179026, чији је носилац Педагошки факултет у Ужицу, а који финансира Министарство просвете и науке Републике Србије. 
Беднарсакаја (Беднарсакая) указује да се категорија експресивности често преплиће са другим значењима и да се у литератури категорије „ескспресивности и емоционалности обично не разликују” (Беднарсакаја 2012: 37). Још средином педесетих година двадесетог века Галкина-Федорук се залагала за разликовање појма експресивност од појма емоционалност, јер експресија обухвата и емоционалност и мисаоност, „она је шири појам од емоционалности у језику” (ГалкинаФедорук 1958: 107). И Пејановић указује да је емоционалност само компонетна експресивности (Пејановић 2016), Ристић да оне представљају тесно повезане компоненте конотације (Ристић 2004), а Тошовић да „свако емоционално није и експресивно, али је свако експресивно емоционално" (Тошовић 2004: 32). Наведени ставови су у складу са мишљењем да је емоционалност компонента експресивности (Арнољд 1973; Лекант 2012; Шаховски 1987; Шаховски 2008) и коришћењем двојног појма за означавање њихове повезаности - „експресивно-емоционално” (Меликјан 2001), нарочито у области лексике (Рожнова 2014). Из изложеног уочава се да је појам експресивности у теоријској литератури био различито тумачен и како указује Пејановић често „неразликован од сличних појава и особина језичких јединица" (Пејановић 2016: 362).

Имајући у виду сложеност појма експресивности у раду ћемо се ограничити на испитивање емоционалне компоненте експресивности на примеру Андрићеве приповетке $У$ завади са светом (Андрић 1963: 17-24). Под емоционалном компонентом експресивности подразумевамо емотивно значење које, према Бабенку, представља „значење у коме је на неки начин представљен (изражен или означен) емотивни смисао”, односно значење „у чијој се семној структури налази сема емотивности одређеног ранга" (према Тошовић 2004: 31). Емоционалну компоненту експресивности истражићемо разматрајући експресивност насловне синтагме приповетке и испитујући понављања у тексту приповетке значењски емоционално маркиране лексеме сумьив.

\section{Експресивност насловне синтагме Андрићеве приповетке Узавади са светом}

Насловна синтагма Андрићеве приповетке $У$ завади са светом састављена је од четири лексеме: две пунозначне речи (именице) и две помоћне (предлози). Подела речи на пунозначне и помоћне припада области лексикологије. Лексикологија се, углавном, „бави пунозначним речима” јер потпуно значење помоћних речи бива јасно „тек онда када су у реченици” (Станојчић/Поповић 2011: 190). Међутим, са становишта експресивности, и помоћне речи могу да буду ознаке за експресију у књижевном тексту. Наведено, наочито важи за узвике, који као маркиране ознаке емотивног стања носе експресију. Они су, по Гортан-Премк, „нерационализовани изрази субјективног стања, осећања, расположења лица које говори" (Гортан Премк 2004: 30). У насловној синтагми Андрићеве приповетке и предлози у функцији помоћних речи представљају ознаке за експресију. То 
се односи на предлог $y$ који се употребљава „са локативом кад значи место где се нешто налази" (Пипер/Клајн 2014: 207). У насловној синтагми овај предлог емотивно маркира положај у коме се неко налази. Да нема тог предлога, да се приповетка зове Завада са светом, члан синтагме у номинативу би имплицирао активни однос исказан именицом завада. Предлог $y$ именицу завада одређује као место на коме се неко налази. У Речнику српскога језика ова именица је објашњена синонимним појмовима као „свађа, расправа и сукоб. 2. прекид односа због сукоба, љутња, непријатељство” (РСЈ 2011: 365). ${ }^{1}$ Друга пунозначна лексема у насловној синтагми, именица свет има више значења. Према Речнику српскога језика, она може да означава: 1) Земљу као планету са свеукопношћу живе и неживе материје на њој; 2) васиону, звездани систем, појединачна небеска тела, 3) целокупну стварност која је доступна људском искуству; 4) људе, људско друштво, људски род и човечанство, али и друштвену средину и друштво у коме се неко креће (РCJ 2011: 1177). Из насловне синтагме приповетке није јасно о каквом свету је реч. Ова значењска неодређеност насловне синтагме представља свестан шум, кодну препреку у разумевању значења чији је циљ стварање експресије. Кодне шумове аутори намерно уносе „да се перципирање избаци из аутоматизма и створи ефекат" (Тошовић 2014: 47). Закључићемо да насловна синтагма Андрићеве приповетке $У$ завади са светом изазива почетну експресију јер иницира радозналост и интересовање читаоца да се приповетка прочита и тако открије о каквој завади и о у каквом свету је реч.

\section{Понављања значењски маркиране лексеме сумюив}

У тематском слојевима Андрићеве приповетке $У$ завади са светом налази се низ каузално повезаних догађаја који остављају последице на сазревање и емотивни свет главног јунака дечака Лазара. Приповедно време приказане предметности обухвата распон од неколико месеци који нису прецизно одређени, већ као период од једне мајске недеље до једне среде почетком новембра. Наведени период се поклапа са школовањем главног јунака у трећем и четвртом разреду основне школе, о чему сазнајемо посредством свезнајућег приповедача који користи треће лице једнине перфекта. Представљени догађаји покренути су случајно: главни јунак прислушкује разговор одраслих. У том разговору пажњу му је заокупила реч сумьив. Он не зна њено значење, али наслућује ,да мора бити нешто врло тешко" (Андрић 1963: 18). Запитаност о значењу мисаоно, емотивно и фантазијски окупира личност и утиче на понашање главног јунака. Кулминацију радње представља јунаково изговарање тајанствене судбоносне речи „која се не казује” (Андрић 1963: 22) и која треба да га пребаци у „тамни свет који га већ одавно тако привлачи" (Андрић 1963: 22). Даљи ток радње нема те-

\footnotetext{
${ }^{1}$ Синоним именице завада - именица свађа, у Речнику српскога језика одређена је као „жучна, жестока, оштра препирка, расправа; бучна расправа непријатељскоr и увредљивог тона, кавга. Прекид односа због сукоба, непријатељски однос, завада" (РСЈ 2011: 1173).
} 
жину спољашње манифесности јер јунаков прелазак границе „која га је делила од тајанственог света сумњивих" (Андрић 1063: 23) други ликови приповетке готово да и не примећују. Само за главног јунака он има велики емотивни значај јер га испуњава страхом и немиром и чини да се осећа као „обележен човек и осуђен кривац” (Андрић 1963: 22) који је у завади са целим светом.

У Андрићевој приповеци лексема сумъив понавља се и варира дванаест пута. Реч у свом морфолошком облику представља придев, у лексичком пунозначну реч, а у семантичком означава човека који „изазива сумњу, неповерење, подозрење (због својих поступака, држања, карактера и сл.)" (РСJ 2011: 1264). Понављање истих речи као одлика експресивности има одлику позитивне редунданце. Већ у првој реченици приповетке читалац се усмерава ка експресивној маркираности наведене лексеме, иако она није изречена. Од стране свезнајућег приповедача сазнаје да је главни јунак био у трећем разреду основне школе „када је нешто начуо о томе” (Андрић 1963: 17). Повезивањем глагола начути, који означава слушну перцепцију, са показном заменицом (томе) остварује се емотивна маркираност јер се може начути само нешто о чему се тихо или тајно говори. Експресивну улогу има и неодређена заменица нешто која имплицира неодређеност значења информације. Читав даљи ток приповедања подстакнут је прислушкивањем разговора за који је почетна реченица представљала психолошку и емотивну припрему. Дечак је скривен слушао разговоре одраслих људи и тако сазнао да неки човек не може да добије ни посла ни зараде. У утврђивању његовог положаја лексема сумњив је употребљена први пут: „Неко је тада рекао: - Неће лако ни добити јер он је сумњив!” (Андрић 1963: 18).

Друго понављање лексеме сумњив има улогу да истакне њено психолошко деловање на главног јунака: „Лазар је пратио све то, али сва његова пажња остала је код речи сумњив" (Андрић 1963: 18). Психолошко деловање лексеме на главног јунака троструко је мотивисано: 1) начином на који је она изговорена (пригушено, али са јаким нагласком), 2) реакцијом коју је изазвала на све присутне: „Сва су лица одједном одрвенила”, разговор је престао и наступила је „нека неприродна тишина у којој се чуло збуњено кашљуцање, али само за тренутак” (Андрић 1963: 18); и 3) неразумевањем њеног значења од стране главног јунака. Неразумевање значења и реакције које изазива вербализација чине да лексема сумьив постане стално присутна рефлексија главног јунака.

У трећем понављању лексема се јавља у облику непотпуне експресивне реченице: „Сумњив!” (Андрић, 1963: 18). Ово понављање има улогу да покаже раст интензитета жеље да јунак нешто више сазна о овој речи о којој поседује само нејасна наслућивања. Лексема се јавља самостално у форми узвичне реченице, као придев који се осамосталио. Наведено показује везаност особине за човека. За главног јунака, то је конкретан човек, Никола, кога су одрасли поменули у разговору. Дакле, јунак изједначава особину са човеком коме се она приписује. Његову радозналост додатно повећава то што је разлог због чега је Никола сумњив нејасан. Нека кривица коју не разуме, мора да постоји. Џаџић је уочио да Андрић не само кривицу, већ и зло и грех, представља на два начи- 
на. Николина кривица одговара првом начину представљања кривице, који је, „дескриптиван, у назнакама, без субјективног осмишљавања тих категорија у самим ликовима”, док други начин „даје конкретан процес доживљаја у лику самом" (Џаџић 1996: 238).

Четврто понављање речи сумњив указује на свесна чињења јунака да сазна узрок кривице и тако открије непознато значење лексеме. Он се код другова распитује „ко је, шта је и какав је сумњиви човек” (Андрић 1963: 19). У овом понављању, придев се јавља у облику одређеног придевског вида (сумњиви) који показује „да је оно на шта се односи именица која је у синтагми с тим придевом нешто одређено или поменуто" (Пипер/Клајн 2014: 131). У одговорима које је добијао од другова лексема се понавља пети пут: „... трећи је тврдио да је његов тата тако јак да може једном руком савладати сваког човека, па и тог Сумњивог." (Андрић 1963: 19). У овом понављању лексема добија облик властите именице: написана је великим словом и представља лично име човека што, такође, указује на процес идентификације човека са особином која му се приписује.

Шесто понављање лексеме везано је за прву конкретну информацију о значењу тајанствене речи коју је јунак добио од своје тетке Миле. ${ }^{2}$ Тим објашњењем је значење лексеме доведено у везу са изговарањем забрањене речи које изазива казну тајанственог и моћног света који управља људима и њиховим судбинама. Где се налази тај свет није просторно локализовано, он је тамо негде. И та просторна неодређеност исказана лексичким спојем тамо негде има функцију емотивног истицања: тамо негде се управља људским животом. Синтагма забрањена реч постаје ново место значењске неодређености за главног јунака. Дечаку је јасно да је забрањена реч узрок, а да је последица њеног изговарања сумњивост, што интензивира радозналост да сазна њено значење.

Седмо и осмо понављање лексеме сумњив дата су у идентичном облику узвичне реченице: „Сумњив!” (Андрић 1963: 19, 20) и представљају емотивни показатељ интензивирања унутрашњих размишљања која постају унутрашња опсесија: „О томе је мислио код куће, на улици, у школи” (Андрић 1963: 19). Мисао изазива и маштања о томе како „под сумњом” живи Никола, човек кога је главни јунак изједначио са особином коју му приписују. Маштања истовремено изазивају и супротстављена осећања: страх и чудну привлачност (Андрић 1963: 20). Долази до унутрашње подвојености. „Тема подвојености једна је од сталних Андрићевих тема” (Радоњић 2016: 739). Страх од „живота под сумњом”, који за главног јунака представља наличје обичног живота и неки њему непознати свет, заправо је страх од непознатог који, по Лавкрафт (Лавкрафт 2005), представља један од најстарих и најјачих облика страхова. Страх се у психолошкој литератури сматра једном од основних људских емоција (Отли/Џонсон Лерд 1996)

${ }^{2}$, „Т је човек који је рекао неку забрањену реч, нешто што се не говори, и због тога је тамо негде одакле се управља људима и њиховим судбинама, код котарског предстојника, уведен у списак сумњивих. Од тог трена њега надзиру и прате у свим његовим поступцима. И... и, ето, укратко: није добро и није лако таквим људима. Уосталом о томе не треба ни мислити ни разговарати" (Андрић 1963: 19). 
и представља „емоцију ишчекивања опасности” (Отли/Џенкинс 2007: 264). Он је и основно обележје наше културе која је, по мишљењу Свенсена, обележена друштвеном дезинтеграцијом (Свенсен 2008). У рационалним слојевима личности човека не привлачи оно што изазива страх. Довођење у везу привлачности са емоцијом страха показује да реакције на емоције често потичу из несвесних слојева личности, што изазива и збуњеност. И атрибут чудна који у Андрићевој приповеци квалитативно неодређено описује именицу привлачност (Андрић 1963: 20) има експресивну улогу. Он показује да је код главног јунака присутна свест о немогућности рационалног објашњења зашто га истовремено привлачи оно што га и плаши. Људи су склони да све оно што не схватају окарактеришу као чудно. На привлачност страха указује и Свенсен ставом да се свет „у коме је сав страх елиминисан, јавља као ужасно мало привлачан” (Свенсен 2008: 80). Пошто је типична реакција на страх покушај да се створи што је могуће већа дистанца између нас и онога што нас плаши, поменути аутор психолошко дејство пријатности као реакције на страх објашњава као добровољно трагање човека за доживљајима који испуњавају одређену његову потребу (Свенсен 2008: 82).

Девето понављање лескеме сумњив ${ }^{3}$ последица је унутрашњег сукоба који се одвија у главном јунаку. Он је видео Николу, човека који „живи под сумњом”. Последица тог сусрета је разочараност која настаје као резултат сукоба унутрашње пројекције и реалности. Човек који је предмет вишемесечних размишљања и маштања главног јунака, човек чија физичка појавност у јунаковој машти отелотворује сумњивост, изгледа сасвим обично и безазлено. Увереност у истинитост субјективне фикције побеђује. Главни јунак теши себе да је неупадљиви изглед, заправо обмана његовог јунака и враћа се маштањима, пребацујући фокус са личности човека на свет коме он припада. Десето понављање лексеме сумњив везано је за тренутак у коме размишљања и маштања достижу кулминацију јер јунак решава да пређе границу „и изговори ту судбоносну реч која се не казује и која оног ко се усуди да је изрекне баца одмах и заувек у свет сумњивих и прокажених" (Андрић 1963: 22). У опису самог тренутка преласка границе и уласка у „свет сумњивих” јавља се придев сумњив, што представља једанаесто понављање лексеме. ${ }^{4}$ Експресивност лексеме истакнута је њеним морфолошким осамостаљивањем које има улогу да укаже на процес унутрашње идентификације сопствене личности са особином која је била предмет вишемесечних размишљања. Сада је главни јунак, а не неко други, сумњив. По психоаналитичком учењу, такво понашање индикатор је деловања подсвесних делова личности

${ }^{3}$ „Требало се одрећи слике коју је себи створио о сумњивом човеку и свих оних узбуђених маштања којима се толико времена осећао везан за њега, али њему су његове унутарње слутње и стрепње биле ближе и драже од овог што се види на сунцу октобарског дана у чаршији" (Андрић 1963: 20).

${ }^{4}$ „Стао је раскорачен насред собе, окренуо се прозорима иза којих је био дан и једнако пролазио свет, стегао је песнице, испрсио се, протегао врат напред и, широко отворених уста, али без гласа, без словца једног, само вољом и мишљу и храпутавим дахом „изговорио”, замислио да изговара, непознату реч која се не казује и не сме казати, а после које се постаје - сумъив." (Андрић 1963: 20) 
који несвесно мотивишу човека и воде у га у унутрашње сукобе. Човек се труди да потисне или држи под контролом сва осећања или афекте који га или плаше или нису друштвено прихватљиви или он сам не разуме њихово порекло. Јунг (Carl Gustav Jung) указује на дубоку подвојеност људског бића: сваки човек у својој природи има тамну страну, сенку, без које не може да постоји (Јунг 1977). Сенка садржи скривене, потиснуте, неповољне и срамотне видове једне личности. За главног јунака она представља забрањену жељу да припада тамном свету сумњивих, да пређе границу изговарањем забрањене речи. Сузуки и Фром (Suzuki i Fromm) сматрају да су несвесно и свесно у човеку друштвено условљени и зависе од образаца осећања и мишљења које друштво обликује, јер да би опстало, друштво мора да уобличава карактер својих чланова тако „да они желе да чине оно што морају да чине” (Сузуки/Фром 1977: 224). У људској заједници „појединац себи не може да дозволи свест о мислима или осећањима која се не подударају са обрасцима његове културе, те је стога принуђен да их потискује” (Сузуки/Фром 1977: 227). И Скинер (Skinner) указује на друштвену контролу људског понашања, путем успостављеног система одобравања или кажњавања (Скинер 1969). Изношење човекове мрачне стране увек изазива последице. У приповеци, изношење мрачне стране за последицу има унутрашњи осећај сукоба, који Андрић описује као заваду са целим светом.

Замишљено изговарање забрањене речи узрок је психичке трауме која је обележила не само детињство, већ и каснији живот главног јунака. О томе сведочи реченица којом приповедач прекида причу о самом догађају: „На жалост, он не зна ни сада како та реч гласи" (Андрић 1963: 22). Цитирана реченица приповедачку перспективу пребацује из прошлог у садашње време и показује „да људске патње имају своју генезу” (Илић 1999: 10), односно да трауматични доживљаји проживљени у периоду детињства остављају последице и у зрелој животној доби. Паул-Луис Томас (Paul-Louis Thomas) указује да је за експресивност „одлучујућа пропорција глаголских облика унутар датог текста” (Томас 2016: 211). У приповеци $У$ завади са светом доминирају глаголски облици за означавање прошлости. Уметање презента у њих има двоструку улогу: показује интензитет трауматичног догађаја кроз дужину његовог трајања у сећањима главног јунака и указује на емотивну важност догађаја, тј. како догађај из прошлости утиче на личност јунака у садашњем тренутку дочаране предметности. ${ }^{6}$

Дванаесто понављање лексеме сумњив, дато је у делу приповетке који описује психолошко стање главног јунака након што је изговорио „забрањену

${ }^{5}$ Истраживања показују да интензивне емоције повећавају дужину трајања и тачност сећања (Линтон 1982; Вагенар 1986; Кристијансон 1992; Стајн и др. 2009).

${ }^{6}$ И у Андрићевој приповеци Прозор главни јунак, сећајући се трауматичног догађаја из детињства, каже: „Целог века се после лечимо од детињства” (Андрић 1963: 60) што, такође, показује деструктивно деловање трауматичних догађаја из детињства на психичку стабилност личности у зрелом добу. 
реч". ${ }^{7}$ Приповедач то психолошко стање описује као претрнутост у којој дечак не осећа ништа, сем дрхтања сопствене речи „ето!” коју је узвикнуо кроз отворени прозор. Дрхтање је описано посредством поређења: „као нагло отпуштена челична опруга" (Андрић 1963: 22). Поређење са челиком има емотивну улогу јер наглашава тежину и унутрашњи притисак који је трпео. И лексема „ето” емотивно је маркиран психолошки знак. Њена експресивно-емотивна улога у дочараној предметности приповетке двоструко је мотивисана: дечак показује другима (свету), али и себи да је довољно снажан за такав чин.

Показатељ унутрашњег стања јунака је и поређење „као да га пробуди” које описује његову реакцију на прво обраћање других након „преласка границе”:

„Када је напуштао „велику собу”, наишла је стара Тасија са музилицом пуном тек помуженог крављег млека и упитала га хоће ли јомуже. То невино и уобичајено питање као да га пробуди" (Андрић 1963: 23).

Наведено поређење показатељ је да јунаково стање није било рационално. Можда зато и прелазак границе не доноси жељено растерећење од страха и немира. Напротив, они расту, јер се дуго чекало на последице. Унутрашња кулминација настаје у тренутку када се дечаку обратила тетка Мила. Она се обраћа народном лексиком и два пута понавља упитну реченицу: - „Еј, Лазаре, на мору возаре!”. Шта је? Што си се замислио? (Андрић 1963: 24). Обраћање лексиком из народне поезије и теткина питања делују на јунака као „моћна струја”. Наведена синтагма наглашава интензитет његове жеље да се ослободи страха. Дечак жели да загњури лице у теткине димије „и да се сит исплаче, као некад кад је био сасвим мали и кад је патио од ноћних мора" (Андрић 1963: 24). Плач има катарзичну улогу прочишћења и ослобађања од унутрашње напетости. Дечак се свом снагом опире тој жељи и његова одлучност побеђује. Приповетка се завршава унутрашњом иницијацијом коју Јеротић дефинише као напуштање ирационалног принципа задовољства и „овладавање реалношћу” (Јеротић 2002: 81).

„У њему су његов страх и његова одлучност хватали сада неку равнотежу и спремали се да живе тако једно поред другог, у ишчекивању оног што ће наићи, што мора наићи" (Андрић 1963: 24).

Међутим, оживљавање страха и одлучности у претходно цитираном одломку показује и њихову појединачну егзистенцију која, на психолошком плану, означава и могућност издвојене доминације и контроле над осталим аспектима личности. Радоњић описује двоструку технику којом је у Андрићевој прози представљена подвојеност ликова: 1) приказивање из спољашње перспективе како лик делује и 2) истицање у првом плану унутрашњости лика и приказивање психолошких процеса (Радоњић 2016: 737-738). У приповеци У завади са светом комбиноване су обе технике представљања подвојености лика. Представљена су размишљања главног јунака, али и његово деловање које је

\footnotetext{
${ }^{7}$ „Невидљиво и њему самом нејасно, он је прешао границу која га је делила од тајанственог света сумњивих" (Андрић 1963: 22-23).
} 
усмерено ка испуњењу тајне жеље која изазива унутрашњи сукоб. Довођење размишљања и деловања у равнотежу, на самом крају приповетке, приказано је као довођење страха и одлучности у равнотежу, у ишчекивању онога што следи и што је неминовно. Наведено наглашава два пута поновљени исти глагол наићи. Експресивност оваквог краја представља, по терминологији Ингардена (Ингарден 1975), једно од „места неодређености” приповетке и позива читаоца на дијалог. Гериг (Гериг 1993) указује да књижевна дела могу да изазову стварне емоције о нереалним догађајима и да су механизми које користимо за разумевање фикције исти као они које користимо за разумевање свакодневног света. У идејним слојевима оваквог завршетка налази се етичка порука да код човека, у неминовном ишчекивању неизвесног, упркос страху, мора да победи одлучност да сачува своју људскост, коју Фром (Fromm) говорећи о заједничкој сржи свих људи, описује као независност и слободу, као сврху по себи, и као способност човека да разликује добро и зло, да научи „да слуша глас своје савести” и да буде „довољно јак да га може следити” (Фром 1998: 65).

\section{Закључно разматрање}

Андрићева приповетка $У$ завади са светом у слојевитој и значењима богатој структури обједињује бројне елементе експресивности. Будући да се експресивност испољава на свим језичким нивоима, у раду смо испитивали само неке њене елементе: експресивну функцију наслова приповетке и експресивну улогу понављања у тексту приповетке значењски маркиране лексеме сумъив. Експресивност стилских фигура, различитих морфолошких облика речи и реченичних конструкција само је спорадично испитивана, у случајевима када се укрштала са експресивношћу претходно наведених елемената, што указује на сложеност испитивања експресивности у књижевном тексту, чак и када је реч о испитивању на микронивоу. При томе, бројност испитиваних експресивних елемената, сама по себи, не доноси књижевном делу, статус уметничког, што Ковачевић објашњава на примеру стилских фигура: „Саме стилске фигуре, без обзира на њихов број, ниједној пјесми не прибављају статус умјетничког а камоли вриједног умјетничког остварења" (Ковачевић 2000: 368). Дакле, елементи експресивности нису значајни сами по себи, већ у саодносу са другим елементима структуре књижевног текста и сви елементи експресивности у Андрићевој приповеци $У$ завади са светом доприносе целокупном уметничком утиску.

Резултати нашег истраживања који су усмерени на емотивну компоненту испитиваних експресивних елемената показују да насловна синтагма приповетке има улогу кодног шума који подстиче радозналост читаоца. Понављања у тексту приповетке значењски маркиране лексеме сумњив представљају позитивну редунданцу која у значењским слојевима текста приповетке представља емотивни показатељ кретања унутрашњих токова свести и подсвести главног јунака. 


\section{ИЗВОРИ}

Андрић 1963: И. Андрић, Децุа, Београд: Просвета.

PCJ 2011: Речник српског језика, редиговао и уредио М. Николић, Нови Сад: Матица српска.

\section{ЛИТЕРАТУРА}

Арнолд 1973: И. В. Арнолдь, Стилистика савременного английского языка (Стилистика декодирования), Ленинград: Просвещение.

Беднарскаја 2012: Л. Д. Беднарская, О различении категорий эмоциональности и экпресивноссти, $y$ : Н. А. Герасименко (ред.), Ращиональное и эмоциональное в русском языке: Международный сборник научых трудов, Москва: Министерство образования и науки РФ / Московский государственений областной университет, 36-41.

Бјелаковић 2016: И. Бјелаковић, Експресивни валери у језику науке код Срба у 18. и 19. веку, Научни састанак слависта у Вукове дане, 45/1, 161-173.

Галкина Федорук 1958: Е. М. Галкина-Федорук, Об экспрессивности и эмоциональности в языке, $y:$ А. И. Ефимов (ред), Сборник статей по языкознанию: Проф. В. В. Виноградову в день его 60-летия, Москва: Издательство Московского университета, 103-124.

Гериг 1993: R. Gerrig, Experriencing Narrative Worlds: On the Psychological Activities of Reading, New Haven: Yale University Press.

Гортан Премк 2004: Д. Гортан-Премк, Полисемија и организација лексичког система у српскоме језику, Београд: Завод за уџбенике и наставна средства.

Илић 1999: П. Илић, У свету Андрићеве уметности, Нови Сад: Змај.

Ингарден 1975: R. Ingarden, Doživljaj, umetničko delo i vrednost, Beograd: Nolit.

Јеротић 2002: В. Јеротић, Индивидуализација и (или) обожење, Beograd: Ars Libri.

Јунг 1977: K. G. Jung, Duh i život, Novi Sad: Matica srpska.

Ковачевић 2000: М. Ковачевић, Стилистика и граматика стилских фигуpa, Крагујевац: Кантакузин.

Лекант 2012: П. А. Лекант, Категория рационального и эмоционального в русском языке и русской речи, Вестник Московского государственного университета, Серия: Русская филология, 5, Москва, 44-48.

Линтон 1982: M. Linton, Transformations of memory in everyday life, in: U. Neisser (eds.), Memory observed. Remembering in natural contexts, San Francisco: Freeman, 77-91.

Лавкрафт 2005: H. P. Lovecraft, Die Literatur der Angst, Frankfurt: Suhrkamp.

Меликјан 2001: В. Ю. Меликян, Словарь. Эмоциональо-экспрессивные обороты живой речи, Москва: Флинта, Наука. 
Отли/Џенкинс 2007: K. Oatley i J. M. Jenkins, Razumijevanje emocija, Jastrebarsko: Naklada Slap.

Отли, Џонсон Лерд 1996: K. Oatley and P. Johnson-Laird, The communicative theory of emotions: Empirical tests, mental models, and implications for social interaction, in: L. Martin, A. Tesser (eds.), Striving and feeling: Interaction among goals, affect, and self-regulation Mahwah/New Jersey: Erlbaum, 363-393.

Пејановић 2016: А. Пејановић, Експресивност као категоријална особина фразеолошких јединица, Научни састанак слависта у Вукове дане, 45/1, 361-367.

Пипер/Клајн 2014: П. Пипер и И. Клајн, Нормативна граматика спског језика, Нови Сад: Матица српска, 2014.

Радоњић 2016: Г. Радоњић, Андрић и традиција свјетске приповјетке: тема подвојеност лика, Зборник Матиие српске за књижевност и језик LXIV/3, Нови Сад, 731-741.

Ристић 2004: С. Ристић, Експресивна лексика у српском језику, Београд: Институт за српски језик и САНУ.

Рожнова, 2014: Е. А. Рожнова, Эмоционально-экспрессивная лексика английского языка и ее нагруженность, Источник: Альманах современной науки и образования, 11(89), Тамбов, 119-121.

Свенсен 2008: L. Svensen, Filozofija straha, Beograd: Geopoetika.

Симић/Јовановић 2002: Р. Симић и Ј. Јовановић, Српска синтакса I-II, Београд: НДСЈ и Јасен.

Скинер 1969: B. F. Skiner, Nauka i ljudsko ponašanje, Cetinje: Obod.

Станојчић/Поповић 2011: Ж. Станојчић и Љ. Поповић. Граматика сриског језика. Београд: Завод за уџбенике.

Стајн и др. 2009: L. N. Stein et al., A Theoretical Approach to Understanding and Remembering Emotional Events, in: L. N. Stein et al (eds.), Memory for Everyday and Emotional Events, New York: Routledge, 15-48.

Сузуки/Фром 1977: D. T. Suzuki i E. From, Zen budizma i psihoanaliza, Beograd: Nolit.

Тошовић 2004: Б. Тошовић, Експресивност. Стил, 25-61. 〈https://www. rastko.rs/cms/files/books/49c94a2930469〉. 12.01.2020.

Tомас 2016: P. L. Thomas, Експресивност при употреби претериних времена, Научни састанак слависта у Вукове дане, 45/1, 203-213.

Фром 1998: Е. Фром, Психоанализа и религија, Београд: Народна књига - Алфа.

Кристијансон 1992: S. A. Christianson (ed.), The Handbook of Emotional and Memory: Research and Theory, Hillsdale/New Jersey: Erlbaum.

Џаџић 1996: П. Џаџић, Сабрана дела. 1. Иво Андрић: есеј, Београд: Завод за уџбенике и наставна средства.

Шаховски 1987: В. И. Шаховский, Категоризаџия эмоций в лексико-семантической системе, Воронеж: Издательство Воронежского универсисета. 
Шаховски 2008: В. И. Шаховский, Лингвистическая теория эмоций, Москва: Гнозис.

Штрасни 2016: Г. Штрасни, Именице са ознаком подругљиво у речнику српскохрватскога књижевног језика, Научни састанак слависта у Вукове дане, 45/1, 349-359.

Вагенар 1986: W. Wagenaar, My memory: a study of autobiographical memory over six years, Congnitive Psychology 18/2, 225-252.

Mirjana M. Stakić

\section{EXPRESSIVENSS OF THE ANDRIĆ'S SHORT STORY QUARREL WITH THE WORLD}

\section{Summary}

We will examine the expressiveness of Andrić's short story U zavadi sa svetom (Quarrel with the World), underlining the emotional component of its expressiveness. We will study the expressiveness of the titular phrase and lexical repetitions of the semantically separated lexeme. The examined expressive linguistic units observed as interrelated elements of a layered and semantically rich structure. Through interpretation, we will analyze the positive code noise and positive redundancy, reflexive-thematic layers of the short story, marked psychological meanings and effects of a traumatic childhood event on one's personality.

Keywords: Serbian language, expressiveness, emotionality, lexeme suspicious, Ivo Andrić, short story U zavadi sa svetom (Quarrel with the World). 